\title{
Antitumor agents bound to silica nanoparticles: potential technology for the remediation of malignant tumors
}

\author{
Young-Hwan Lee ${ }^{\star}$, Jung-Ok Lee ${ }^{1}$ and Kyung-Soo Chun \\ Department of Chemistry, Kyungwon University, Sungnam City, Kyunggido 461-701, Korea \\ ${ }^{1}$ Korea Research Institute of Chemistry Technology, PO BOX 107, Yusong, Daejon, 305-343, Korea \\ (Received September 8, 2010; Accepted December 2, 2010)

\section{실리카 나노 입자에 결합된 항종양제: 악성종양 치료를 위한 새로운 치료 방법 \\ 이영환 ${ }^{\star} \cdot$ 이정옥 ${ }^{1} \cdot$ 전경수 \\ 경원대학교 화학과, ${ }^{1}$ 한국화학연구소 \\ (2009. 9. 8. 접수, 2010. 12. 2. 승인)}

\begin{abstract}
Commercially widely used antitumor agents such as hydroxy urea, 6-mercaptopurine monohydrate, cytosine arabinoside, cyclophosphamide monohydrate and uracil were reacted with 3-(triethoxysilyl)propyl isocyanate and the product hydrolyzed to give silica nanoparticles bound antitumor agents ranging from $10 \mathrm{~nm}$ to micron-sized aggregates. The silyl isocyanate derivative was also reacted neat with water to give hybrid organicsilica nanoparticles containing $-\mathrm{CH}_{2}-\mathrm{CH}_{2}-\mathrm{CH}_{2}-\mathrm{NH}-\mathrm{COOH}$ or the corresponding decarboxylated propylamine groups depending on solvent and temperature employed. In vitro tests these functionalized silica nanoparticles were effective in the treatment of malignant tumor cells but had little or no effect on normal cells. Malignant human lung, ovarian, melanoma, CNS(Central nervous system) and colon tumor cells were used in this research. The use of silica as a carrier medium in the present research serves as a model material due to its ready functionalization via silation. The proof of concept established by the results suggests that the technique may be applied to other, more biocompatible carrier nanoparticles.
\end{abstract}

요 약: 현재 상업적으로 널리 사용 되여 지고 있는 항암제인 hydroxy urea, 6-mercaptopurine monohydrate, cytosine arabinoside, cyclophosphamide monohydrate 그리고 uracil를 3-(triethoxysilyl) propyl isocyanate 와 반응시켜 항암제가 붙어있는 3-(triethoxysilyl)propyl amide (compound I)을 합 성한후 물과 가수분해 반응시켜 항암제가 결합된 silica 나노입자 $(10 \mathrm{~nm} \sim$ micronparticles)를 만들 수 있었다. Silyl isocyanate 유도체들은 물과 반응하여 유기물질-silica 나노입자가 포함된 $-\mathrm{CH}_{2}-\mathrm{CH}_{2}-$ $\mathrm{CH}_{2}-\mathrm{NH}-\mathrm{COOH}$ 그룹이나 혹은 온도와 용매등 반응조건에 따라서 decarboxylated 된 propylamine 그 룹이 생성되었다. 생체외 시험에서 항암제가 결합된 silica 나노입자는 종양 세포 제거에 효과적이고 정상세포에 거의 영향을 미치지 않는 것으로 나타났다. 그리고 악성 종양인 폐, 난소, 악성 흑색종,

Corresponding author

Phone : +82-(0)31-750-5408 Fax : +82-(0)31-750-5389

E-mail : leeyh@kyungwon.ac.kr 
중추신경계(CNS)와 결장 종양 세포가 이 연구에 사용되었다. 현재의 연구에서 전달매체 로서 silica는 silation 반응으로 손쉽게 나노입자를 얻을 수 있으므로 본 연구에 쉽게 이용 할 수 있다. 결과로부 터 이 기술은 보다 부작용이 적은 생체 의약품에 적합한 carrier nanoparticles에 적용 될 수 있을 것 으로 판단된다.

Key words: silica nanoparticle, antitumor agents, 3-(triethoxysilyl)propyl isocyanate

\section{Introduction}

Commercially available antitumor agents are known to cause serious side effects in patients when administered near. To alleviate this problem many researchers have vigorously investigated alternative methods of delivery, including missile therapy ${ }^{1}$ polymer-drug mixtures ${ }^{2}$ and anchoring antitumor agents into tumor cells $^{3}$ Recently, a nanocapsule system ${ }^{4}$ and an agent micellar entrapment method ${ }^{5}$ have been reported. Moreover, nanoparticle systems using various materials such as chitosan-acrylic acid, ${ }^{6}$ cyclodextrine-polyisobutylcyanoacrylate, ${ }^{7}$ oligonucleotides ${ }^{8}$ and erythrocyte ghosts $^{9}$ have been reported as diluent carriers of antitumor agents.

The results reported in this publication differ from the aforementioned because the selected antitumor agents are covalently bound to the carrier silica nanoparticles either in core-shell fashion or integrated throughout the solid.

In this work, 3-(triethoxysilyl)propylisocyanate was used as a starting material to react with commercially available antitumor agents to give the compound I.

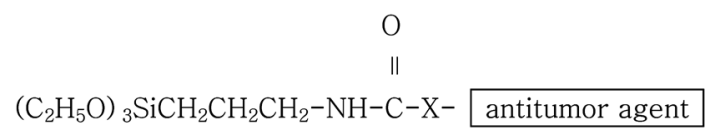

where $\mathrm{X}$ is $-\mathrm{O},-\mathrm{S},-\mathrm{NH}$, and/or $-\mathrm{COO}$

\section{Compound I}

All of the antitumor agents employed have -OH, $-\mathrm{NH},-\mathrm{NH}_{2},-\mathrm{SH}$, and/or - $\mathrm{COOH}$ functional group(s) for reaction with the isocyanate functional group. The triethoxysilyl unit in compound I then reacted with water to give silica nanoparticles containing bound antitumor agents (Compound II).

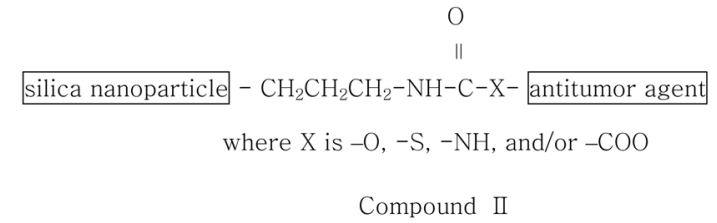

Scheme 1. shows the whole reaction scheme.

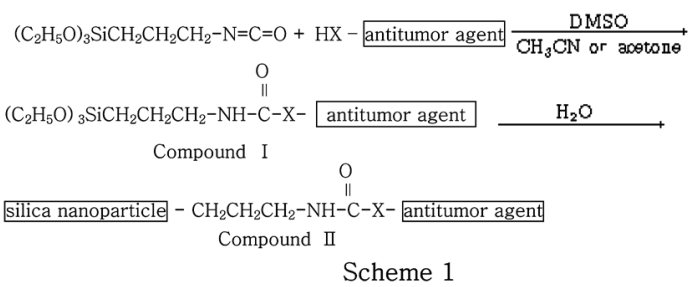

Alternatively, Scheme 2 also yields the desired silica nanoparticles containing bound antitumor agent but with higher silica: antitumor agent ratio.

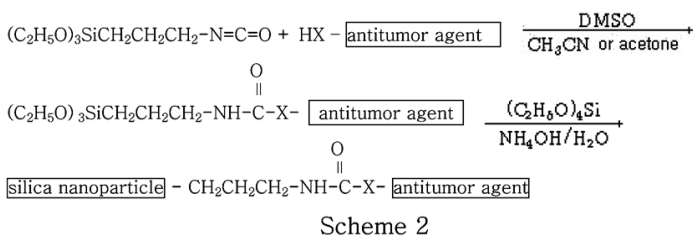

The reaction of 3-(triethoxysilyl)propylisocyanate with water in the presence of DMSO as a solvent at 38 ${ }^{\circ} \mathrm{C}$ gave compound III which shows very remarkable effect on the various malignant tumors.

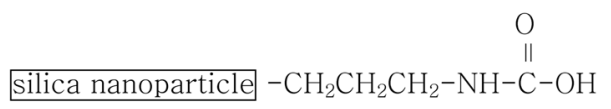

Compound III

However, the reaction of 3-(triethoxysilyl)propylisocyanate with water in the presence of $\mathrm{CH}_{3} \mathrm{CN}$ as a solvent at $25{ }^{\circ} \mathrm{C}$ gave compound IV.

$$
\text { silica nanoparticle }-\mathrm{CH}_{2} \mathrm{CH}_{2} \mathrm{CH}_{2}-\mathrm{NH}_{2}
$$

\section{Compound IV}


This means that decarboxylation of the initially formed carbamic acid group in compound III depends not only on temperature but solvent.

\section{Experimental section}

All reagent grade chemicals were used as received unless otherwise noted. Deionized water was used for synthesis and binding experiments. Tetrahydrofuran, 6mercaptopurine-monohydrate, 2-amino-6-purinthiol, cytosine arabinoside, uracil, cyclophosphamide-monohydrate, tetraethoxysilane, and 3-(triethoxy-silyl)propylisocyanate were obtained from Aldrich Chemical Co. (Milwakee, WI, U.S.A.). Ammonium hydroxide

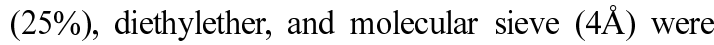
obtained from Merck Chemical Co.(German). In vitro experiments were conducted by SRB (sulforhodamine B) assay. Shimadzu (Japan) IR-470, and FTIR-8701, Vision (Korea) refrigerated centrifuge VS15CF, and Hitach (Japan) S-4700 field-emission scanning electron microscope instruments were used to obtain data, respectively.

\subsection{Reaction of 3-(triethoxysilyl)propylisocy-} anate with hydroxyurea(1).

In a $250 \mathrm{~mL}$ round-bottom flask equipped with magnetic stirrer, a thermometer, and $100 \mathrm{~mL}$ dropping funnel with calcium chloride drying tube was placed hydroxyurea $\left(1.9 \mathrm{~g}, 2.5 \times 10^{-2}\right.$ mole) with dried tetrahydrofuran $(70 \mathrm{~mL})$ with stirring at $25^{\circ} \mathrm{C}$. 3-(triethoxysilyl)propylisocyanate $\left(6.1 \mathrm{~mL}, 2.5 \times 10^{-2}\right.$ mole $)$ with dried tetrahydrofuran $(20 \mathrm{~mL})$ was added dropwise

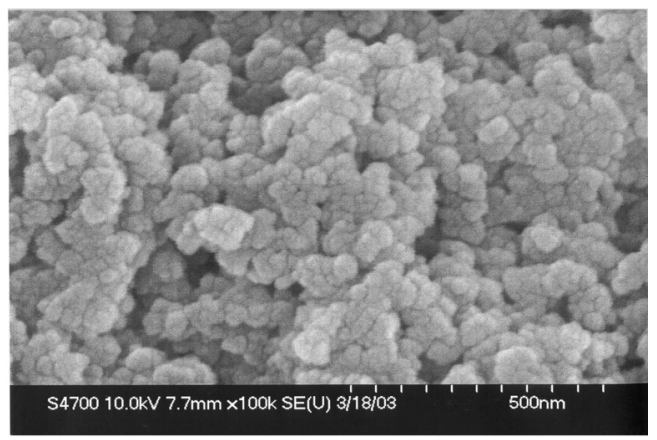

Fig. 1. SEM of silica nanoparticles containing bound cyclophosphamide. through the dropping funnel with stirring at $25{ }^{\circ} \mathrm{C}$. The solution was stirred for $12 \mathrm{~h}$ at $38{ }^{\circ} \mathrm{C}$, and then, the solution was transferred into a $200 \mathrm{~mL}$ beaker. The mixture of tetrahydrofuran $(25 \mathrm{~mL})$, distilled water $(23 \mathrm{~mL})$, and ammonium hydroxide $(3.5 \mathrm{~mL}$, $25 \%$ ) was added to the solution in the beaker with stirring at $38{ }^{\circ} \mathrm{C}$. The solution was stirred at $38{ }^{\circ} \mathrm{C}$ for $24 \mathrm{~h}$. The white precipitate formed slowly and was collected by centrifugation at $10,000 \mathrm{rpm}$, then washed with absolute ethanol $(100 \mathrm{~mL})$ twice.

The white precipitate was dried at $90{ }^{\circ} \mathrm{C}$ for $24 \mathrm{~h}$. (yield $=70 \%$ )

IR (KBr): 3400(-OH, s), 2800 2990 (sat.-CH, m), 1700 and $1660(\mathrm{C}=\mathrm{O}, \mathrm{s}), 1120(\mathrm{C}-\mathrm{O}, \mathrm{s}) \mathrm{cm}^{-1}$

SEM: $25 \mathrm{~nm}$.

\subsection{Reaction of 3-(Triethoxyslyl)propylisocy-} anate with 6-mercaptopurine $\cdot \mathrm{H}_{2} \mathrm{O}(\underline{2})$.

In a $250 \mathrm{~mL}$ round-bottom flask equipped with magnetic stirrer, a reflux condenser, a thermometer, and a $100 \mathrm{~mL}$ dropping funnel with calcium chloride drying tube, was placed 6-mercaptopurine $\cdot \mathrm{H}_{2} \mathrm{O}$ (3.4 $\left.\mathrm{g}, 2.0 \times 10^{-2} \mathrm{~mole}\right)$ with dried acetone $(65 \mathrm{~mL})$ with stirring at $25{ }^{\circ} \mathrm{C}, 3$-(triethoxysilyl)propylisocyanate $\left(9.9 \mathrm{~mL}, 4.0 \times 10^{-2}\right.$ mole) with dried acetone $(35 \mathrm{~mL})$ was added dropwise through the dropping funnel with stirring at $25^{\circ} \mathrm{C}$.

The solution was stirred for $12 \mathrm{~h}$ at $100{ }^{\circ} \mathrm{C}$, cooled to $25{ }^{\circ} \mathrm{C}$, then transferred into a beaker $(200 \mathrm{~mL})$. The mixture of dried acetone $(20 \mathrm{~mL})$, distilled water $(18 \mathrm{~mL})$, and ammonium hydroxide $(3.0 \mathrm{~mL}$, $25 \%$ ) was added to the solution in the beaker with stirring at $25{ }^{\circ} \mathrm{C}$. The solution was stirred at $38{ }^{\circ} \mathrm{C}$ for $12 \mathrm{~h}$, and a yellow precipitate was formed slowly.

The solids were collected by centrifugation at 10,000 $\mathrm{rpm}$, and washed with dried acetone $(100 \mathrm{~mL})$ twice, then dried at $90{ }^{\circ} \mathrm{C}$ for $24 \mathrm{~h}$. (yield $=60 \%$ )

IR (KBr): 3400(-NH, s), 3100(C=C-H, s), 2900 2990 (sat.-CH, s), $1670(\mathrm{C}=\mathrm{O}, \mathrm{m}), 1620(\mathrm{C}=\mathrm{N}, \mathrm{s}) \mathrm{cm}_{-}{ }^{1}$

SEM: $50 \mathrm{~nm}$.

\subsection{Reaction of 3-(triethoxysilyl)propylisocy-} anate with cytosine arabinoside(3).

In a $250 \mathrm{~mL}$ round-bottom flask equipped with 
magnetic stirrer, a reflux condenser, a thermometer, and a $100 \mathrm{~mL}$ dropping funnel with calcium chloride drying tube was placed cytosine arabinoside $(1.0 \mathrm{~g}$, $3.6 \times 10^{-3}$ mole) with dried dimethylsulfoxide $(30 \mathrm{~mL})$ with stirring at $25^{\circ} \mathrm{C}, 3$-(triethoxysilyl)propylisocyanate $\left(0.9 \mathrm{~mL}, 3.6 \times 10^{-3}\right.$ mole) with dried dimethylsulfoxide $(20 \mathrm{~mL})$ was added dropwise through the dropping funnel with stirring at $25^{\circ} \mathrm{C}$. The solution was refluxed at $100{ }^{\circ} \mathrm{C}$ for $24 \mathrm{~h}$, cooled to $25^{\circ} \mathrm{C}$, then transferred into a beaker $(200 \mathrm{~mL})$. The mixture of dimethylsulfoxide $(10 \mathrm{~mL})$, distilled water $(3.2 \mathrm{~mL})$, and ammonium hydroxide $(0.5 \mathrm{~mL}, 25 \%)$ was added to the solution in the beaker with stirring at $25^{\circ} \mathrm{C}$.

The solution was heated at $38{ }^{\circ} \mathrm{C}$ for $24 \mathrm{~h}$, but no precipitate was formed. Therefore, tetraethylorthosilicate $(0.8 \mathrm{~mL})$ was added to the above solution at $25{ }^{\circ} \mathrm{C}$, and the mixture was stirred for $24 \mathrm{~h}$. A brown precipitate was formed slowly, collected by centrifugation at $10,000 \mathrm{rpm}$, and washed with absolute ethanol $(200 \mathrm{~mL})$ twice, then was dried at $90{ }^{\circ} \mathrm{C}$ for 24 h. (yield $=90 \%$ )

IR (KBr): 3400 (-OH, s), 2900 2980 (sat.-CH, s), 1690 and $1650(\mathrm{C}=\mathrm{O}, \mathrm{s}), 1100(\mathrm{C}-\mathrm{O}, \mathrm{s}) \mathrm{cm}^{-1}$

SEM: aggregate

\subsection{Reaction of 3-(triethoxysilyl)propyliso- cyanate with cyclophosphamide $\cdot \mathrm{H}_{2} \mathrm{O}(\underline{4})$}

In a $100 \mathrm{~mL}$ round-bottom flask equipped with magnetic stirrer, a reflux condenser, a thermometer, and a $100 \mathrm{~mL}$ dropping funnel with calcium chloride drying tube, was placed cyclophosphamide $\cdot \mathrm{H}_{2} \mathrm{O}(3.0$ g, $1.0 \times 10^{-2}$ mole) with dried dimethylsulfoxide (30 $\mathrm{mL}$ ) with stirring at $25^{\circ} \mathrm{C}$. 3-(Triethoxysilyl)propylisocyanate $\left(5.0 \mathrm{~mL}, 2.0 \times 10^{-2}\right.$ mole $)$ with dried dimethylsulfoxide $(20 \mathrm{~mL})$ was added dropwise through the dropping funnel at $80^{\circ} \mathrm{C}$ for $24 \mathrm{~h}$.

The solution was cooled at $25{ }^{\circ} \mathrm{C}$, transferred into a beaker $(200 \mathrm{~mL})$ of dimethylsulfoxide $(10 \mathrm{~mL})$, distilled water $(9 \mathrm{~mL})$, and ammonium hydroxide $(1.5 \mathrm{~mL})$ were added with stirring at $25{ }^{\circ} \mathrm{C}$. The solution was stirred for $24 \mathrm{~h}$ at $25^{\circ} \mathrm{C}$.

The brown precipitate was collected by centrifugation at 10,000 rpm and washed with absolute ethanol $(100 \mathrm{~mL})$ twice, then dried at 90 for $24 \mathrm{~h}$ (yield =
$90 \%)$.

IR (KBr): 3400 (-OH, m), 2900 2980 (sat.-CH, $\mathrm{m}), 1650(\mathrm{C}=\mathrm{O}, \mathrm{s}), 1120(\mathrm{C}-\mathrm{O}, \mathrm{m}) \mathrm{cm}_{-}{ }^{1}$

SEM: $25 \mathrm{~nm}$.

\subsection{Reaction of 3-(triethoxysilyl)propylisocy-} anate with uracil(모)

In a $100 \mathrm{~mL}$ round-bottom flask equipped with magnetic stirrer, a reflux condenser, a thermometer, and a $100 \mathrm{~mL}$ dropping funnel with calcium chloride drying tube was placed uracil $\left(5.7 \mathrm{~g}, 5.0 \times 10^{-2}\right.$ mole $)$ with dried dimethylsulfoxide $(30 \mathrm{~mL})$ with stirring at $25{ }^{\circ} \mathrm{C}$. 3-(Triethoxysilyl)propylisocyanate $(12.3 \mathrm{~mL}$, $5.0 \times 10^{-2}$ mole) with dried dimethylsulfoxide $(20 \mathrm{~mL})$ was added dropwise through the dropping funnel with stirring at $25{ }^{\circ} \mathrm{C}$. The solution was stirred at 38 ${ }^{\circ} \mathrm{C}$ for $24 \mathrm{~h}$, cooled to at $25^{\circ} \mathrm{C}$, then transferred into a beaker $(200 \mathrm{~mL})$.

The mixture of dimethylsulfoxide $(200 \mathrm{~mL})$, distilled water $(18 \mathrm{~mL})$ and ammonium hydroxide $(3 \mathrm{~mL}$, $5 \%$ ) was added to the solution in the beaker with stirring at $25^{\circ} \mathrm{C}$.

The solution was stirred for $24 \mathrm{~h}$ at $25{ }^{\circ} \mathrm{C}$ while a white precipitate formed slowly. The white precipitate was collected by centrifugation at $10,000 \mathrm{rpm}$, washed with absolute ethanol $(100 \mathrm{~mL})$ twice, then dried at $90{ }^{\circ} \mathrm{C}$ for $24 \mathrm{~h}$. (yield $=30 \%$ )

IR (KBr): 3200 (-NH, s), $3100(\mathrm{C}=\mathrm{C}-\mathrm{H}, \mathrm{s}), 2900$ 2980 (sat.-CH, s), 1700 and $1650(\mathrm{C}=\mathrm{O}, \mathrm{s}) \mathrm{cm}^{-1}$

SEM: $25 \mathrm{~nm}$.

\subsection{Reaction of 3-(triethoxysilyl)propylisocy-} anate with water $(\underline{6})$.

In the $250 \mathrm{~mL}$ beaker was placed 3-(triethoxysilyl) propylisocyanate $\left(12.3 \mathrm{~mL}, 5.0 \times 10^{-2}\right.$ mole) with dimethylsulfoxide $(30 \mathrm{~mL})$ with stirring, distilled water $(18 \mathrm{~mL})$ with dimethylsulfoxide $(20 \mathrm{~mL})$ was added slowly with stirring at $25^{\circ} \mathrm{C}$.

The solution was stirred at $38^{\circ} \mathrm{C}$ for $24 \mathrm{~h}$. A white precipitate which formed slowly was collected by centrifugation at $10,000 \mathrm{rpm}$, washed with absolute ethanol $(100 \mathrm{~mL})$ twice, and air-dried at $25{ }^{\circ} \mathrm{C}$ for 24 h. $($ yield $=32 \%)$

IR (KBr): 3400 (-NH, s), 2900 2980 (sat.-CH, s), 
$1650(\mathrm{C}=\mathrm{O}, \mathrm{s}), 1150(\mathrm{C}-\mathrm{O}, \mathrm{s}) \mathrm{cm}^{-1}$

SEM: $25 \mathrm{~nm}$.

\subsection{Sample 7}

Vial A: hydroxyurea $\left(2.0 \mathrm{~g}, 2.5 \times 10^{-2} \mathrm{~mole}\right)$ in dimethylsulfoxide $(15 \mathrm{~mL})$

Vial B: 3-(triethoxysilyl)propylisocyanate $(6.1 \mathrm{~mL}$, 0.025 mole) in dimethylsulfoxide $(15 \mathrm{~mL})$

Vial A and vial B were mixed together along with water just prior to injection into the tumor cells.

\subsection{Sample 8}

Vial A: cyclophosphamide $\mathrm{H}_{2} \mathrm{O}\left(1.0 \mathrm{~g}, 3.3 \times 10^{-3}\right.$ mole) in acetonitrile $(15 \mathrm{~mL})$

Vial B: 3-(triethoxysilyl)propylisocyanate $(1.6 \mathrm{~mL}$, $6.6 \times 10^{-3}$ mole $)$ in acetonitrile $(15 \mathrm{~mL})$
Vial A and vial B were mixed together along with water just prior to injection into the tumor cells.

\subsection{Sample 9}

Vial A: uracil $\left(1.1 \mathrm{~g}, 1.0 \times 10^{-2}\right.$ mole $)$ in dimethylsulfoxide $(15 \mathrm{~mL})$

Vial B: 3-(triethoxysilyl)propylisocyanate $(2.4 \mathrm{~mL}$, $\left.1.0 \times 10^{-2} \mathrm{~mole}\right)$ in dimethylsulfoxide $(10 \mathrm{~mL})$

Vial A and vial B were mixed together along with water just prior to injection into the tumor cells.

\section{Results and discussion}

The tumor cells used in this experiment were as follows.

A 549: human lung

Table 1. The effect of silica nanoparticles containing bound hydroxyurea agent (1) against various tumor cells

\begin{tabular}{crrrrr}
\hline \hline \multirow{2}{*}{$\begin{array}{c}\text { Conc. } \\
(\mu \mathrm{g} / \mathrm{mL})\end{array}$} & \multicolumn{5}{c}{ Cells } \\
\cline { 2 - 6 } & A549 & SK-OV-3 & SK-MEL-2 & XF498 & HCT15 \\
\hline 0.1 & 103.1034 & 91.8485 & 105.0623 & 100.1347 & 100.8493 \\
0.3 & 104.4828 & 87.7596 & 103.1184 & 99.1244 & 97.0276 \\
1 & 95.4680 & 90.6166 & 101.8224 & 99.6632 & 99.3631 \\
3 & 91.6256 & 86.0822 & 95.6667 & 100.5725 & 99.1507 \\
10 & 68.6207 & 81.5477 & 95.5047 & 101.6164 & 101.9108 \\
30 & 42.8079 & 70.8276 & 81.3709 & 100.4041 & 65.1805 \\
\hline
\end{tabular}

Table 2. The effect of silica nanoparticles containing bound 6-mercaptopurine(2) against various tumor cells

\begin{tabular}{cccccc}
\hline \hline \multirow{2}{*}{$\begin{array}{c}\text { Conc. } \\
(\mu \mathrm{g} / \mathrm{mL})\end{array}$} & A549 & SK-OV-3 & SK-MEL-2 & XF498 & HCT15 \\
\cline { 2 - 6 } & 68.7533 & 97.0606 & 73.9446 & 72.8690 & 86.3636 \\
0.1 & 65.3050 & 95.1223 & 43.3254 & 25.9188 & 73.5178 \\
0.3 & 23.0769 & 70.4106 & 41.9147 & 20.5696 & 33.7945 \\
1 & 19.5225 & 45.2288 & 40.5041 & 19.6459 & 9.2885 \\
10 & 11.6711 & 22.9854 & 36.8945 & 19.0302 & -7.5221 \\
30 & 8.5411 & 6.5893 & 6.4827 & 10.7177 & -39.3229 \\
\hline
\end{tabular}

Table 3. The effect of silica nanoparticles containing bound arabinoside(3) against various tumor cells

\begin{tabular}{cccccc}
\hline \hline \multirow{2}{*}{$\begin{array}{c}\text { Conc. } \\
(\mu \mathrm{g} / \mathrm{mL})\end{array}$} & \multicolumn{5}{c}{ Cells } \\
\cline { 2 - 6 } & A549 & SK-OV-3 & SK-MEL-2 & \multicolumn{1}{c}{ XF498 } & HCT15 \\
\hline 0.1 & 90.9515 & 102.0575 & 103.0335 & 99.8627 & 98.1567 \\
0.3 & 87.3134 & 98.0601 & 97.1182 & 89.7339 & 95.0845 \\
1 & 84.6549 & 96.4141 & 98.1041 & 100.8240 & 88.9401 \\
3 & 76.1194 & 91.4147 & 91.2030 & 94.9871 & 71.5822 \\
10 & 34.3284 & 78.6612 & 82.1405 & 91.1073 & 49.1551 \\
30 & 8.4422 & 62.1133 & 39.7099 & 57.2189 & 30.4147 \\
\hline
\end{tabular}


Table 4. The effect of silica nanoparticles containing bound cyclophosphamide (4) against various tumor cells

\begin{tabular}{ccrrrc}
\hline \hline \multirow{2}{*}{$\begin{array}{c}\text { Conc. } \\
(\mu \mathrm{g} / \mathrm{mL})\end{array}$} & A549 & SK-OV-3 & SK-MEL-2 & XF498 & HCT15 \\
\cline { 2 - 5 } & 91.6135 & 99.0217 & 98.7222 & 98.2755 & 96.5443 \\
0.1 & 86.1206 & 101.3340 & 99.9201 & 92.3524 & 88.5529 \\
0.3 & 73.0750 & 97.7470 & 93.2515 & 97.9756 & 59.3952 \\
1 & 65.6204 & 95.4643 & 93.9303 & 97.0009 & 69.1145 \\
10 & 56.2040 & 80.0193 & 80.6329 & 97.8257 & 65.8747 \\
30 & 46.6405 & 65.7304 & 54.2777 & 91.4152 & 55.9395 \\
\hline
\end{tabular}

Table 5. The effect of silica nanoparticles containing bound uracil agent (5) against various tumor cells

\begin{tabular}{cccccc}
\hline \hline \multirow{2}{*}{$\begin{array}{c}\text { Conc. } \\
(\mu \mathrm{g} / \mathrm{mL})\end{array}$} & \multicolumn{5}{c}{ Cells } \\
\cline { 2 - 6 } & A549 & SK-OV-3 & SK-MEL-2 & XF498 & HCT15 \\
\hline 0.1 & 104.7344 & 100.4001 & 99.6358 & 95.0476 & 98.5586 \\
0.3 & 104.1557 & 99.5713 & 99.3121 & 95.2404 & 96.0360 \\
1 & 87.8485 & 101.0288 & 95.5083 & 93.3751 & 92.6126 \\
3 & 82.8511 & 93.7987 & 98.4219 & 92.7963 & 81.4414 \\
10 & 82.3777 & 88.7976 & 86.6464 & 92.5068 & 76.3964 \\
30 & 76.2230 & 79.6528 & 53.7481 & 94.0826 & 77.2973 \\
\hline
\end{tabular}

Table 6. The effect of silica nanoparticles containing bound $-\mathrm{CH}_{2} \mathrm{CH}_{2} \mathrm{CH}_{2} \mathrm{NHCOOH}$ agent (6) gainst various tumor cells

\begin{tabular}{cccccc}
\hline \hline \multirow{2}{*}{$\begin{array}{c}\text { Conc. } \\
(\mu \mathrm{g} / \mathrm{mL})\end{array}$} & A549 & SK-OV-3 & SK-MEL-2 & XF498 & HCT15 \\
\cline { 2 - 6 } & 109.3776 & 102.7013 & 104.8950 & 93.8719 & 107.2979 \\
$\times 10^{6}$ & 109.6567 & 103.8171 & 102.4475 & 93.4540 & 89.0532 \\
$\times 10^{5}$ & 102.4418 & 100.6753 & 95.2373 & 88.3937 & 98.7417 \\
$\times 10^{4}$ & 99.4418 & 89.2241 & 86.1750 & 82.9619 & 84.5234 \\
$\times 10^{3}$ & 74.4565 & 60.0382 & 18.1082 & 64.0669 & 33.8157 \\
$\times 10^{2}$ & -43.4599 & -84.0236 & -47.9647 & -74.5935 & -72.8000 \\
$\times 10$ dilution & & & & & \\
\hline
\end{tabular}

Table 7. The effect of hydroxyurea in DMSO/3-(triethoxysilyl)propylisocyanate in DMSO(7) injection against various tumor cells

\begin{tabular}{crrrrr}
\hline \hline \multirow{2}{*}{$\begin{array}{c}\text { Conc. } \\
(\mu \mathrm{g} / \mathrm{mL})\end{array}$} & \multicolumn{1}{c}{ A549 } & SK-OV-3 & SK-MEL-2 & \multicolumn{1}{c}{ XF498 } & HCT15 \\
\cline { 2 - 6 } & 100.7236 & 96.6462 & 99.2143 & 96.8929 & 104.4378 \\
$\times 10^{6}$ & 101.9497 & 102.7859 & 99.3452 & 99.6144 & 103.8421 \\
$\times 10^{5}$ & 83.5377 & 96.6191 & 100.7333 & 94.4662 & 99.1958 \\
$\times 10^{4}$ & -2.5743 & 82.9333 & 89.0002 & 54.6635 & 75.4579 \\
$\times 10^{3}$ & -11.5512 & 39.2521 & 53.3818 & 5.8343 & 31.9136 \\
$\times 10^{2}$ & -98.0198 & -99.6277 & -92.4017 & -98.5262 & -85.3445 \\
$1: 10$ dilution & & & &
\end{tabular}

SK-OV-3: human ovarian

SK-MEL-2: human melanoma

XF 498: human CNS

HCT 15: human colon

The following results (Tables 1 9) show the antitumor activities in vitro (the values are from +100 to -100 where +100 means the most of tumor cells were intact, and -100 means the most of tumor cells were dead).

Tables 1 and 3 show that silica nanoparticles containing bound hydroxyurea (1) and cytosine araboniside (3) have effect on lung tumor only while 
Table 8. The effect of cyclophosphamide $\cdot \mathrm{H}_{2} \mathrm{O}$ in DMSO/3-(triethoxysilyl)propylisocyanate in DMSO( $(8)$ injection against various tumor cells

\begin{tabular}{crrrrr}
\hline \hline \multirow{2}{*}{$\begin{array}{c}\text { Conc. } \\
(\mu \mathrm{g} / \mathrm{mL})\end{array}$} & \multicolumn{5}{c}{ Cells } \\
\cline { 2 - 6 } & A549 & SK-OV-3 & SK-MEL-2 & XF498 & HCT15 \\
\hline$\times 10^{6}$ & 100.4898 & 102.1234 & 96.3624 & 93.9653 & 102.0612 \\
$\times 10^{5}$ & 96.7755 & 100.0552 & 96.2316 & 86.4731 & 101.1949 \\
$\times 10^{4}$ & 91.3469 & 97.1596 & 94.3474 & 80.6433 & 100.7968 \\
$\times 10^{3}$ & 86.5510 & 90.7894 & 85.8685 & 65.2491 & 99.9701 \\
$\times 10^{2}$ & 58.4490 & 70.7687 & 47.5564 & 50.7885 & 89.1860 \\
$1: 10$ dilution & -77.2937 & -87.0427 & -59.6061 & -94.7924 & -94.8228 \\
\hline
\end{tabular}

Table 9. The effect of uracil in DMSO/3-(triethoxysilyl)propylisocyanate in $\mathrm{DMSO}(\underline{9})$ injection against various tumor cells

\begin{tabular}{cccccc}
\hline \hline \multirow{2}{*}{$\begin{array}{c}\text { Conc. } \\
\mu \mathrm{g} / \mathrm{mL})\end{array}$} & A549 & SK-OV-3 & SK-MEL-2 & XF498 & HCT15 \\
\cline { 2 - 6 } & 99.3594 & 99.1036 & 100.0267 & 100.2129 & 99.5192 \\
$\times 10^{6}$ & 99.5596 & 102.6893 & 100.8008 & 100.8043 & 99.2080 \\
$\times 10^{5}$ & 96.3964 & 101.8744 & 102.8295 & 97.4215 & 100.8485 \\
$\times 10^{4}$ & 98.3584 & 100.3531 & 100.6406 & 93.5419 & 98.8686 \\
$\times 10^{3}$ & 71.6917 & 67.4024 & 77.9246 & 74.0966 & 19.1911 \\
$\times 10^{2}$ & -71.4191 & -96.8724 & -92.9045 & -80.1523 & -96.3361 \\
$1: 10$ dilution & &
\end{tabular}

In the data (Tables 1 6), the dried silica nanoparticles containing bound antitumor agent powder were suspended in the solvents such as dimethylsulfoxide or acetonitrile and then shaken vigorously before the injection to the malignant tumor cells.

silica nanoparticles containing bound 6-mercaptopurine $\cdot \mathrm{H}_{2} \mathrm{O}(\underline{2})$ and compound $\underline{6}$ give broad effect on all tumor cells (Table 2 and 6).

It is also possible that 3-(triethoxysilyl)propylisocyanate with DMSO and antitumor agent with DMSO/ $\mathrm{H}_{2} \mathrm{O}$ mixed together before injection into tumor cells. After the mixed solution together was injection into tumor cells, silica nanoparticles containing bound antitumor was formed in the cells where most of tumor cells were destroyed (see Table 7, 8 and 9).

However, in the data (Tables 7 9), antitumor agent was dissolved in dimethylsulfoxide before it mixed together with 3-(triethoxysilyl)propylisocyanate/DMSO. After two above solutions were mixed together, the solution was shaken very vigorously for $1 \mathrm{~h}$. Then, the sufficient amount of distilled water was added to the above solution with vigorous stirring. It is ready for injection within ten minute when the milky silica nanoparticles could be observed.

By considering Tables 7 9, antitumor effect increased very highly when antitumor agent/water with 3(triethoxysilyl)propylisocyanate was injected directly to malignant tumor cells since silica nanoparticles containing bound antitumor agent was formed inside of tumor cell directly. Therefore, remediation point of view, direct injection of antitumor agent along with 3-(triethoxysilyl)propylisocyanate was desirable.

\section{References}

1. Higashi, Sohei (Nanocarrier Co., Ltd., Japan). Farumashia 2002, 38(4), 345-346 (Japan).

2. (a) Xu, Jingya (Fannin Bioscience, Inc., USA) PCT Int. Appl. WO 00 61,788 (C1. C12Q), 19 Oct 2000, US Appl. 291,234,13 Apr 1999; 65pp. (Eng).

(b) Rihova, B. (Polymer Materials Research Group, University of Gent, 9000 Ghent, Belg.). Proc. Int. Symp. Controlled Release Bioact. Mater. 1999, $26^{\text {th }}, 627-$ 628 (Eng).

(b) Deggi, Neil P; Soon-Shiong, Patrick; Magdassi, Shlomo; Sahadevan, David D. (Vivorx Pharmaceuticals, Int., USA) PCT Int. Appl. WO 99 00,113 (C1. A61K9/ 22), 7 Jan 1999, US Appl, 926,155,9 Sep 1997; 175pp. (Eng). 
(d) Lavi, Sara; Satchi-Fainaro, Ronit (Ramot-University Authority for Applied Research and Industrial Development Ltd., Israel) PCT Int. Appl. WO 02 07,670 (C1. A61K), 31 Jan 2002, US Appl. 668,714, 22 Sep 2000; 66pp. (Eng).

(e) Lavi, Sara; Satchi-Fainaro, Ronit (Ramot-University Authority for Applied Research and Industrial Development Ltd., Israel) PCT Int. Appl. WO 02 07,671 (C1. A61K), 31 Jan 2002, US Appl. 668,713, 22 Sep 2000; 73 pp. (Eng).

(f) Fotinos, Spiros; O'Halloran, David; Zolotarsky, Yelena (Lavipharm Laboratories Inc., USA) PCT Int. Appl. WO 02 54,997 (C1. A61F13/00), 18 Jul 2002, US Appl. PV260, 587, 9 Jan 2001; 20pp. (Eng).

(g) Liggins, Richard; Murphy, Larry; Guan, Dechi (Angioteth Pharmaceuticals Inc., Can.) PCT Int. Appl. WO 02 72,150 (C1. A61K47/48), 19 sep 2002, US Appl. PV337,935, $7 \mathrm{~N}$

3. Nizard, Philippe; Gross, David-Alexandre; Chenal, Alexandre; Beaumelle, Bruno; Kosmatopoulos, Konstadinos; Gillet, Daniel (Deparetment d'Ingenierie et d'Etudes des Proteines, CEA-Saclay, 91191 Gif-sur-Yvette, FR.). Journal de la Societe de Biologie 2001, 195(3), 229234(Fr).

4. Unger, Gretchen M. (Genesegues, Inc., USA) PCT Int. Appl. WO 01 64,164 (C1. A61K), 7 Sep 2001, US Appl. PV185,282, 28 Fed 2000; 70 pp. (Eng).

5. (a) Burman, Anand C.; Mukherjee, Rama; Khattar, Dhiraj; Kumar, Mukesh; Bala, Honey; Shrivastava, Rajiv Kumar (Dabur Research Foundation, India) U.S. US 6,365,191 (C1. 424-489; A61K9/14), 2 Apr 2002, IN Appl. 2000/DE641, 11 Jul 2000; 8 pp., Cont.-in-part of U.S. Ser. No. 401,927. (Eng).

(b) Maitra, Amarnath; Sahoo, Sanjeeb Kumar, Ghosh, Prasanta Kuma; Burman, Anand C.; Mukherjee, Rama; Khattar, Dhiraj; Kumar, Mukesh; Paul, Soumendu (Dabur Research Foundation; Delhi University, India) U.S. US 6,322,817 (C1. 424-489; A61K47/30), 27 Nov 2001, IN Appl. 1999/DE263, 17 Feb 1999; 10 pp. (Eng).

6. Fukumori, Yoshinobu; Ichikawa, Hideki; Tokumitsu, Hiroyuki; Shikata, Futoshi; Miyamoto, Masahito; Watanabe, Testuya (Faculty of Pharmaceutical Sciences and High Technology Research Center, Kobe Gakuin University, Kove, Japan 651-2180), Int. Conf. Process. Mater. Prop. Proc., $2^{\text {nd }}$ 2000, 453-458 (Eng).

7. Da Silverira, Monza; Ponchel, Gilles; Duchene, Dominique; Couvreur, Patrick; Puisieux, Francis (Bioalliance Pharma (S.A.); Monza Da Silverira, Airton, Fr.) PCT Int. Appl. WO 99 43,359 (C1. A61K47/48), 2 Sep 1999, FR Appl. 1998/2,429, 27 Feb 1998; 56 pp. (Fr).

8. Balland, Olivier; Saison-Behmoaras, Tula; Garestier, Therese; Helene, Claude (Laboratorie de Biophysique, Museum National Histoire Naturelle, 75231 Paris, Fr.). NATO ASI Ser., Ser. A 1996. 290 (Targeting Drugs 5), 131-142 (Eng).

9. Jain, S; Jain, N. K. (Department of Pharmaceutical Sciences, DR. H. S. Gour University, Sagar, 470003 India). Proc. Int. Symp. Controlled Release Bioact. mater. 1997, $24^{\text {th }}$, 857-858 (Eng).

10. R. Partch; E Powell; Y-H Lee; M. Varshney; S. Kim; N. Barnard; D. Shah; D.Dennis; T. Morey. 2003 Kluwer Academic publishers, Y, G, Gogotsi and I. V. Uvarova (eds.), 27-40. 